\title{
Applying a hierarchisation method to a biodiversity hotspot: Challenges and perspectives in the South-Western Alps flora
}

\author{
Maëlle Le Berre ${ }^{\mathrm{a}}$, Virgile Noble ${ }^{\mathrm{a}}$, Mathias Pires ${ }^{\mathrm{a}}$, Gabriele Casazza ${ }^{\mathrm{b}}$, Luigi Minuto ${ }^{\mathrm{b}, \mathrm{c}}$, \\ Mauro Mariotti $^{\mathrm{b}}$, Sylvain Abdulhak ${ }^{\mathrm{d}}$, Noémie Fort ${ }^{\mathrm{d}}$, Frédéric Médail ${ }^{\mathrm{e}}$, Katia Diadema ${ }^{\mathrm{a}, *}$ \\ ${ }^{\text {a }}$ Conservatoire botanique national méditerranéen de Porquerolles (CBNMed), 34 avenue Gambetta, 83400 Hyères, France \\ b Dipartimento di Scienze della Terra, dell'Ambiente e della Vita (DISTAV), Università di Genova, Corso Europa 26, 16132 Genova GE, Italy \\ c Giardini Botanici Hanbury, Centro di servizi di ateneo, Università di Genova, Corso Montecarlo 43, 18039 Latte IM, Italy \\ ${ }^{\mathrm{d}}$ Conservatoire botanique national alpin (CBNA), Domaine de Charance, 05000 Gap, France \\ e Institut méditerranéen de biodiversité et d'écologie marine et continentale (IMBE), Aix Marseille Université/CNRS/IRD/AU, Campus Aix, Technopôle de l'Environnement \\ Arbois-Méditerranée, F-13545 Aix-en-Provence cedex 4, France
}

\section{A R T I C L E I N F O}

\section{Keywords:}

Conservation priorities

Threatened flora

Endemic flora

Biogeography

South-Western Alps

\begin{abstract}
A B S T R A C T
The South-Western Alps host a great diversity of vascular plants, and especially endemic taxa. Thus, setting up a hierarchisation of patrimonial taxa of this biogeographical territory is needed in order to determine the main conservation concerns of flora. We adapted a hierarchisation method which leans on two criteria representing different kinds of rarity, and a third criterion which incorporates potential threats. This hierarchisation goes further than the objectives assigned to red lists and protection lists because it assesses taxa by taking into account the territorial context, using a standardised method, objective and reproducible. The classification of 913 patrimonial taxa into four concern categories aims to improve the available financial and human resources allocation for conservation measures.
\end{abstract}

\section{Introduction}

For many years, biodiversity decline has been a global concern; thereby the conservation of threatened taxa has become a major issue (Cardinale et al., 2012; Mace, Possingham, \& Leader-Williams, 2007; Millennium Ecosystem Assessment, 2005; Vitousek, 1994). However, protection of all the taxa or ecosystems is not an achievable goal owing to wildlife's extreme diversity and finite allocated budgets. Setting up a hierarchisation of highest conservation concerns taxa is needed to define priority goals and to rationalise the means to implement conservation actions (Coates \& Atkins, 2001; Gauthier, Debussche, \& Thompson, 2010; Marsh et al., 2007). In fact, biodiversity conservation in a given area requires different steps. The first step is usually risk or threats assessment, for example setting up red lists of threatened species developed by the International Union for Conservation of Nature (IUCN). Setting up a hierarchisation is often a second step (Henle et al., 2013; Pullin, Sutherland, Gardner, Kapos, \& Fa, 2013; Wilson, Carwardine, \& Possingham, 2009); it could target geographical assets (e.g. Rodrigues et al., 2004) or biological assets, as habitats (e.g. Berg et al., 2014), species (e.g. Gauthier et al., 2010) or populations (e.g. Bonin, Nicole, Pompanon, Miaud, \& Taberlet, 2007). The next step is usually conservation projects or actions priority-setting (e.g. Joseph, Maloney, \& Possingham, 2009). Finally, the last step consists in conservation actions success assessment.

Current conservation needs rarely follow administrative areas, regulatory lists or threat status defined by red lists, especially in a relatively narrow area which includes regional biodiversity hotspots in which territory responsibility is highest (Keller \& Bollmann, 2004; Schmeller et al., 2008). Red lists of threatened animal and plant species developed with IUCN criteria constitute an objective assessment of extinction risk in a given area, but do not constitute a priority list for species long term conservation, because they were not created for this purpose (IUCN, 2012). However, red lists are often mistakenly considered as a hierarchical list of priorities for conservation actions, and thus conservation priorities are mainly or even only based on extinction risk. Although extinction risk is a critical component of priority-setting systems, it is important to take into account other factors to maximise conservation actions efficiency (Fitzpatrick, Murray, Paxton, \& Brown, 2007; Miller et al., 2006). Therefore, resource allocation based only on IUCN categories is not the most efficient way to help species recovery or to minimise extinction rates (Marsh et al., 2007). Likewise, regulatory lists are not directly applicable to select priority species because they

\footnotetext{
* Corresponding author.

E-mail address: k.diadema@cbnmed.fr (K. Diadema).
} 
often depend on policy resolutions, are subject to uncertainty of expert assessment and are spatially restricted (Jiménez-Alfaro, Colubi, \& González-Rodríguez, 2010). However, priority lists can be used to set up protection lists (e.g. Gauthier et al., 2010; Martín et al., 2010; Schatz, Gauthier, Debussche, \& Thompson, 2014).

A hierarchisation classifies assets according to selected criteria. Many approaches choose a great number of criteria, up to 30 criteria (e.g. Millsap, Gore, Runde, \& Cerulean, 1990; Reece \& Noss, 2014; Gaiarsa, Alencar, Valdujo, Tambosi, \& Martins, 2015). Usually, these criteria can be gathered in 3 main groups: threats (or vulnerability), which is often assessed as taxa IUCN status, rarity (or local distribution), and territorial responsibility (or endemism or international importance) (e.g. Gauthier et al., 2010; Schatz et al., 2014). Beside these main criteria, other criteria are sometimes used, e.g. taxonomic distinctiveness, ongoing management, protection status, economic and social values, ecological feature... (e.g. Freitag \& van Jaarsveld, 1997; Carter, Hunter, Pashley, \& Rosenberg, 2000; Pärtel et al., 2005; Bacchetta, Farris, \& Pontecorvo, 2012). Among the methods for targeting species, we can distinguish focal species selection methods and setting priorities methods, and among the latter we can distinguish « point-scoring " methods (or cumulative systems) and " rule-based » methods (or categorical systems) (Jiménez-Alfaro et al., 2010; Mace et al., 2007). Point-scoring methods are widely known, quantitative, reproducible and objective methods, and are based on readily measurable variables (Jiménez-Alfaro et al., 2010). In this study, we adapted the point-scoring method developed by Gauthier et al. (2010), a method which uses a small number of criteria, relatively easy to assess for a great number of taxa, and embodying the three main kinds of criteria. This method is easily reproducible and can be adapted to different administrative or biogeographical areas, different scales, and different plant groups. Different applications of the Gauthier et al. (2010) method (Gauthier, Foulon, Jupille, \& Thompson, 2013; Kricsfalusy \& Trevisan, 2014; Maciel, Oliveira-Filho, \& Eisenlohr, 2016; Schatz et al., 2014) all used the three same criteria, but assessed them in different ways, according to their particular context.

The South-Western Alps, located at the interface between the Alps mountains and the Mediterranean region, host many endemic plants, with very restricted distribution areas but shared between two countries, France and Italy. Therefore, a hierarchisation of taxa not applied to an administrative area but to a biogeographical area is a consistent approach with global conservation concerns. In fact, the biogeographical conservation approach (e.g. Ladle \& Whittaker, 2011) enables to improve the definition of protection issues which is often biased by approaches reduced to administrative areas and whose methods and objectives can vary from an area to another (Pärtel et al., 2005). Inside the Mediterranean basin, one of the 35 biodiversity hotspots on a global scale (Médail \& Myers, 2004), Maritime and Ligurian Alps (which are an integrative part of South-Western Alps) constitute one of the 10 regional biodiversity hotspots. Biodiversity hotspots are defined as areas where exceptional concentrations of endemic species undergo exceptional loss of habitat (Myers, Mittermeier, Mittermeier, da Fonseca, \& Kents, 2000). They are both an endemism centre and a glacial refuge for Mediterranean and alpine flora (Casazza, Zappa, Mariotti, Médail, \& Minuto, 2008; Médail \& Diadema, 2009; Noble \& Diadema, 2011). The South-Western Alps have a great originality of flora with more than 150 endemic and subendemic taxa (Aeschimann, Rasolofo, \& Theurillat, 2011). Moreover, with the population increase and tourism boom, many low altitude taxa are critically threatened of extinction (Médail \& Verlaque, 1997; Noble et al., 2015; Salanon, Grandili, Kulesza, \& Pintaud, 1994). Refuge areas, containing a great biodiversity, are also threatened by human impacts because they are submitted to important pressures (Médail \& Diadema, 2006).

The purpose of this work is to rank patrimonial taxa of the SouthWestern Alps flora, a biodiversity hotspot, based on a limited number of standardised criteria readily available, aiming to prioritise their conservation concerns, and to compare this hierarchisation results with red lists and protection lists status.

\section{Study area and taxa}

\subsection{Study area}

The study area corresponds to the definition of the South-Western Alps according to Aeschimann et al. (2011), extended to Provençal peripheral mountains, because it matches the distribution ranges of many endemic species (e.g. Berardia subacaulis, Campanula rotundifolia subsp. macrorhiza, Fritillaria involucrata, Helictotrichon sempervirens, Sempervivum calcareum etc.). In order to implement an efficient conservation, the study area must reflect the real distribution of species, not administrative boundaries. This geographical unit is not strictly homogeneous from a biogeographical point of view, because it is located at the limit between temperate Europe and the Mediterranean basin (Takhtajan, 1986), but it is a consistent ensemble in terms of geomorphology, in relation to its geological history, and reflects the reality of biological processes. This territory is a continuum from Mediterranean to alpine environments, going from sea level to more than $4000 \mathrm{~m}$ above the sea level. This particular location is one of the explanatory components of diversity and originality of the flora of this area (Noble \& Diadema, 2011). The study area (Fig. 1) extends on about $43,000 \mathrm{~km}^{2}: 5000 \mathrm{~km}^{2}$ in Italy (12\%) and $38,000 \mathrm{~km}^{2}$ in France $(88 \%)$. $80 \%$ of Provence-Alpes-Côte d'Azur region (PACA, France) and $50 \%$ of Liguria region (Italy) are included in the study area. Two other administrative regions are also marginally included: Auvergne-RhôneAlpes (France) and Piemonte (Italy).

\subsection{Taxonomic targets}

This work targets patrimonial taxa (vascular plants and mosses) which include: (i) endemic or subendemic taxa in the study area, (ii) threatened taxa, and (iii) taxa protected by law.

Endemic taxa distribution is entirely included in the study area and subendemic taxa distribution is included at least at $80 \%$ in the study area. Threatened taxa are classified in IUCN categories: CR (critically endangered), EN (endangered) or VU (vulnerable) in the national red lists in France and in Italy, or in the regional red lists in Liguria, Piemonte and Provence-Alpes-Côte d'Azur (PACA) (Arillo et al., 2005; Noble et al., 2015; Rossi et al., 2013; UICN France, FCBN, MNHN, 2012). Protected taxa have a protection status at European, national (France or Italy) or regional (Liguria, Piemonte, PACA or AuvergneRhône-Alpes) levels. Exogenous taxa were excluded from this analysis, just as those not found since 1990. In total, 913 taxa are ranked, which represents about a quarter of the indigenous flora of the study area.

The occurrence data come (i) from the database SILENE-Flore of the Conservatoire botanique national méditerranéen de Porquerolles (CBNMed) and the Conservatoire botanique national alpin (CBNA) (http://flore.silene.eu) for PACA region, (ii) from the flora database of CBNA for Auvergne-Rhône-Alpes region, (ii) from the Libios database of the Agenzia Regionale per la Protezione dell'Ambiante Ligure (ARPAL) and of the Parco Naturale del Marguareis for Liguria region, and (iv) from the database of the Parco Naturale Alpi Marittime for Piemonte region. These geo-localised data were combined through a web-service developed in the framework of European program Alcotra ${ }^{\circ} 192$ BIODIVAM (http://biodivam.eu) based on a shared taxonomic reference document adapted for the study from TAXREF V5 (Gargominy et al., 2012) for France and from Pignatti (1982) for Italy. In total almost 400,000 occurrence data were used in this work.

\section{Methods and results}

\subsection{Selection and quantification of criteria}

This hierarchisation method for taxa is adapted from the point- 


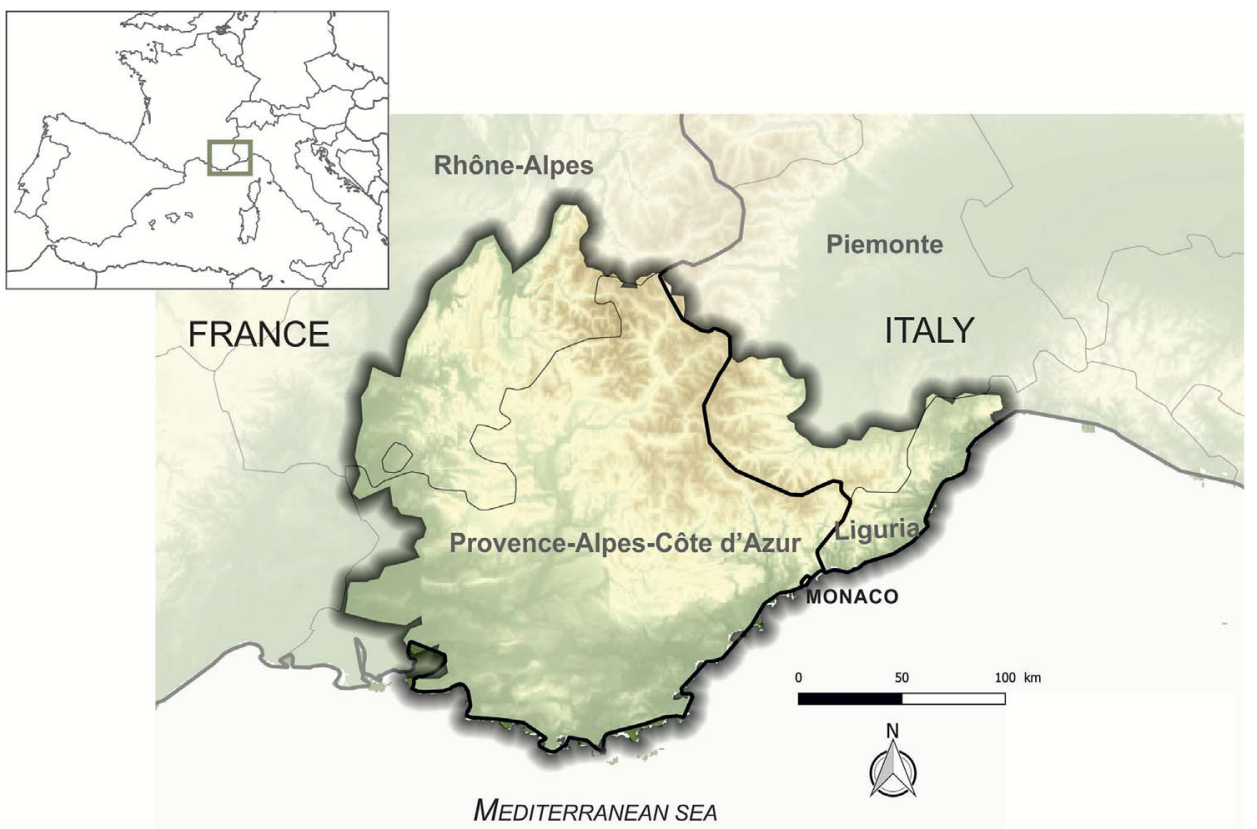

Fig. 1. Study area: the South Western Alps. It includes parts of four different administrative regions of two different countries, France and Italy.

MEDITERRANEAN SEA

scoring method developed by Gauthier et al. (2010). The three selected criteria are biogeographical rarity (adapted from the regional responsibility criterion), local rarity and potential threats to the taxa. This last criterion is assessed through two sub-criteria, habitat vulnerability and populations occurring in artificialised areas. Each criterion or sub-criterion is divided in 5 classes ranked from 1 to 5,5 representing the score for the rarest or most threatened taxa (Table 1 ).

Biogeographical rarity criterion aims to prioritise taxa with a restricted global distribution (Gauthier et al., 2013). It is assessed using chorology, a typology of global distribution of taxa (Aeschimann, Lauber, Moser, \& Theurillat, 2004; Pignatti, 1982; Tison \& de Foucault, 2014; Tison, Jauzein, \& Michaud, 2014). Endemic taxa were defined as their distribution area is entirely included in the study area, whereas subendemic taxa were defined as $80 \%$ of their distribution area is included in the study area. Among widely distributed taxa (scoring 1 or 2) a bonus point is assigned to those reaching the limit of their distribution area, and those which have a disjointed distribution area.

Local rarity criterion aims to prioritise locally rare taxa in the study area, because they have a greater probability of going extinct because of stochastic factors (Gauthier et al., 2010), even though the link between intrinsic rarity and extinction is not systematic (cf. Gaston, 1994). This criterion is assessed as the number of occurrence grid cells $(5 \mathrm{~km} \times 5 \mathrm{~km})$ of taxa in the study area. To limit bias of the grid position, the average number of occurrences obtained from 100 randomly placed grids was calculated (software R 3.0.2). The quantile method was used to split local rarity scores into 5 equal size classes.

Potential threats criterion aims to prioritise taxa threatened by extrinsic factors which can lead to a fast population decline and local extinction (Kricsfalusy \& Trevisan, 2014). Two factors are taken into account for the assessment: habitat vulnerability and artificialisation. For each taxon, threats score was calculated as the average of habitat vulnerability score and artificialisation score.

Habitat vulnerability assesses the risk of habitat loss (in terms of surface or functionality) including both natural and artificial causes (Gauthier et al., 2010). It is defined as its sensitivity to pressures or threats and its capacity to face the damages caused by these pressures or threats (Bensettiti, Puissauve, Lepareur, Touroult, \& Maciejewski, 2012). This assessment was carried out in 5 steps (Fig. 2) and based on EUNIS typology (EUropean Nature Information System) (Louvel,
Gaudillat, \& Poncet, 2013; Bajjouk et al., 2015a,b vol. 1 and 2). To limit potential bias ensuing from expert opinion, we used the Delphi technique (Hsu \& Sandford, 2007; Mukherjee et al., 2015). 33 EUNIS habitats (level 2) were assessed. We assigned one or two habitat types to taxa: in most cases we can consider that they have one or two main habitats, even if they can be found in others.

Soil artificialisation assessment aims to prioritise taxa whose populations occur in artificial areas (Vimal, Geniaux, Pluvinet, Napoleone, \& Lepart, 2012). We chose to add artificialisation sub-criterion because in this biodiversity hotspot, it represents a major threat to taxa through habitat loss (e.g. Médail \& Diadema, 2006). The vectorial shape from CORINE Land Cover, 2012 (level 1) was used to extract artificial lands: « artificial surfaces » (code 1), « arable land » (code 21) and « permanent crops » (code 22) were considered as artificial (software QGIS 2.6.1). For each taxon, an artificialisation percentage was calculated as the average artificialisation rate of all of its occurrence grid cells. The quantile method was used to split artificialisation scores into 5 equal size classes.

\subsection{Hierarchisation of taxa}

The final score was calculated using the sum of scores summarisation method (e.g. Millsap et al., 1990; Sapir, Shmida, \& Fragman, 2003; Zhang, Gao, Wang, \& Cao, 2015): the final score is equal to the sum of biogeographical rarity score, local rarity score and threats score (Table 2). The equivalent class discretisation method was used to gather taxa into four priority levels (Table 3). Only one taxon obtained the maximum score of 15, Artemisia molinieri, and two taxa obtained the minimum score of 3, Huperzia selago and Ranunculus glacialis. More than $80 \%$ of taxa obtained a final score between 5.5 and 11 . Only $4 \%$ of the taxa are classified as very high concern, and $15 \%$ as low concern. Very high and high concern taxa represent a little less than half of the taxa (44\%) (Table 3).

\subsection{Criteria determining conservation concerns}

Taxa distribution is presented for each selected criterion and each conservation concern group (Fig. 3). For very high concern taxa (Fig. 3a), local rarity criterion is determining: all the taxa obtained a 


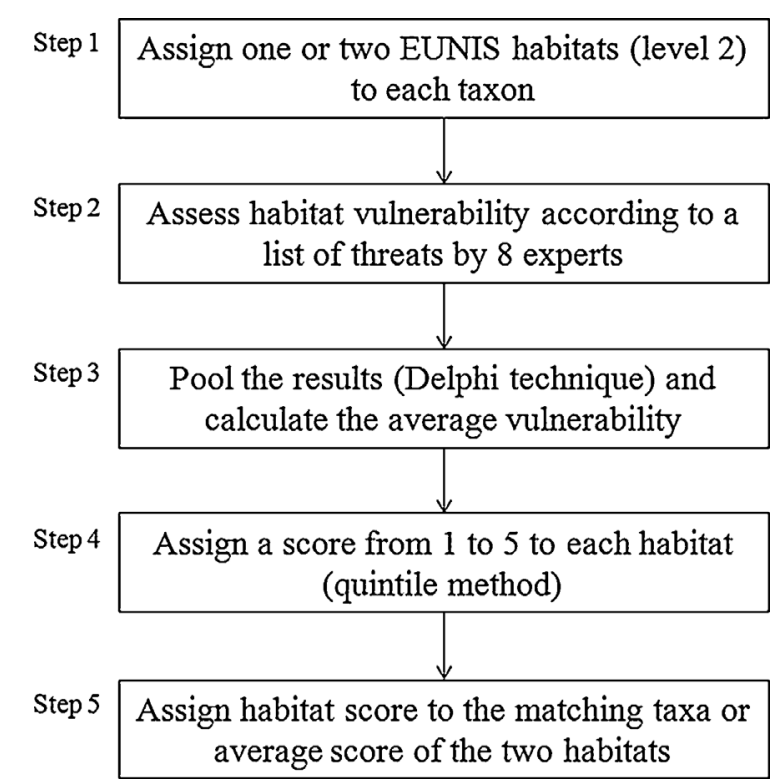

Fig. 2. Assessment of the sub-criterion habitat vulnerability in 5 steps. One or two habitats were assigned to each taxon according to its known ecological preferences. Then the assessment was carried out independently by eight experts using a list of 13 pressures and threats (appendix 7 in Bensettiti et al., 2012). The final assessment was constructed using the Delphi technique, an information return process which enables and encourage participants to review their initial judgments in order to reach an opinion consensus (De Lange, Sala, Vighi, \& Faber, 2010; Hsu \& Sandford, 2007). Habitat vulnerability was calculated as the average of the 5 most important threats on each habitat, then turned into scores using the quintile method.

score of 5 for this criterion (less than 5 occurrence grid cells), except one that obtained a score of 4 . Other criteria are also important, with about two thirds of taxa occurring in more than $30 \%$ of artificialised areas, about half being endemic of the study area, and about $40 \%$ occurring in threatened habitats. Two groups of locally rare and artificialised areas occurring taxa can be distinguished: (i) endemic taxa of the study area (17 taxa) with very narrow distributions (e.g. Acis fabrei), and (ii) taxa with wider global distribution but occurring in very threatened habitats (e.g. Cyperus capitatus).

For high concern taxa (Fig. 3b), local rarity is also a determining criterion: more than $70 \%$ of taxa obtained a score of 4 or 5 (less than 12 occurrence grid cells), and only one taxon obtained a score of 1 (Santolina decumbens, endemic of Provence). Artificialisation criterion is also important with about one third of taxa occurring in more than $30 \%$ artificialised areas. Biogeographical rarity and habitat vulnerability are quite evenly distributed. However, more than half of endemic taxa of the study area are classified as high concern. Two groups of locally rare taxa can be distinguished: (i) endemic taxa of the study area (e.g. Ballota frutescens), and (ii) taxa with wider global distribution but threatened by habitat vulnerability or soil artificialisation (e.g. Hydrocotyle vulgaris).

For moderate concern taxa (Fig. 3c), the four criteria are important, with about $70 \%$ of taxa occurring in moderately vulnerable habitats, about $60 \%$ relatively common in the study area (more than 34 occurrence grid cells), and more than half not occurring in artificial areas (less than $4 \%$ of populations in artificial areas) and having a wide distribution (e.g. Dracocephalum austriacum).

For low concern taxa (Fig. 3d), local rarity criterion is also determining: $97 \%$ of taxa obtained a score of 1 or 2 (more than 34 occurrence grid cells), and none obtained a score of 4 or 5 for this criterion. Biogeographical rarity and habitat vulnerability are also important: more than $85 \%$ of taxa obtained a score of 1 or 2 , and none endemic or subendemic taxa was classified in this group. Habitat vulnerability is the only criterion for which some taxa obtained a score of 5 (Juncus filiformis, Pinguicula vulgaris, Primula farinosa and Triglochin 
Table 2

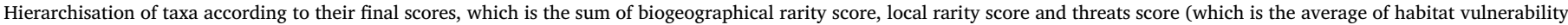
score and artificialisation score), for the 50 top-ranked taxa (see the hierarchisation of all taxa in the appendix).

\begin{tabular}{|c|c|c|c|c|c|c|c|c|}
\hline Taxa names & Biogeo. rarity score & Local rarity score & Habitat vuln. score & Artif. score & Threats score & Final score & Rank & Concern \\
\hline Artemisia molinieri & 5 & 5 & 5 & 5 & 5 & 15 & 1 & Very high \\
\hline Romulea arnaudii & 5 & 5 & 3 & 5 & 4 & 14 & 2 & Very high \\
\hline Armeria arenaria subsp. pradetensis & 5 & 5 & 2 & 5 & 3.5 & 13.5 & 3 & Very high \\
\hline Acis fabrei & 5 & 5 & 2 & 4 & 3 & 13 & 4 & Very high \\
\hline Centaurea paniculata subsp. gallinariae & 5 & 5 & 2 & 4 & 3 & 13 & 4 & Very high \\
\hline Centaurea pseudocineraria & 5 & 5 & 1 & 5 & 3 & 13 & 4 & Very high \\
\hline Molineriella minuta & 3 & 5 & 5 & 5 & 5 & 13 & 4 & Very high \\
\hline Romulea florentii & 5 & 5 & 2 & 4 & 3 & 13 & 4 & Very high \\
\hline Scrophularia canina subsp. ramosissima & 3 & 5 & 5 & 5 & 5 & 13 & 4 & Very high \\
\hline Senecio leucanthemifolius subsp. crassifolius & 5 & 4 & 3 & 5 & 4 & 13 & 4 & Very high \\
\hline Teucrium dunense & 3 & 5 & 5 & 5 & 5 & 13 & 4 & Very high \\
\hline Verbena supina & 3 & 5 & 5 & 5 & 5 & 13 & 4 & Very high \\
\hline Armeria arenaria subsp. peirescii & 5 & 5 & 2 & 3 & 2.5 & 12.5 & 5 & Very high \\
\hline Armeria belgenciensis & 5 & 5 & 2 & 3 & 2.5 & 12.5 & 5 & Very high \\
\hline Bellevalia trifoliata & 3 & 5 & 4 & 5 & 4.5 & 12.5 & 5 & Very high \\
\hline Iberis linifolia subsp. stricta & 5 & 5 & 1 & 4 & 2.5 & 12.5 & 5 & Very high \\
\hline Matthiola tricuspidata & 3 & 5 & 4 & 5 & 4.5 & 12.5 & 5 & Very high \\
\hline Taraxacum leucospermum & 5 & 5 & 2 & 3 & 2.5 & 12.5 & 5 & Very high \\
\hline Achillea maritima & 2 & 5 & 5 & 5 & 5 & 12 & 6 & Very high \\
\hline Anthyllis cytisoides & 3 & 5 & 3 & 5 & 4 & 12 & 6 & Very high \\
\hline Aristolochia paucinervis & 3 & 5 & 3 & 5 & 4 & 12 & 6 & Very high \\
\hline Artemisia insipida & 5 & 5 & 2 & 2 & 2 & 12 & 6 & Very high \\
\hline Catapodium hemipoa & 2 & 5 & 5 & 5 & 5 & 12 & 6 & Very high \\
\hline Centaurea jordaniana subsp. aemilii & 5 & 5 & 2 & 2 & 2 & 12 & 6 & Very high \\
\hline Centaurea jordaniana subsp. balbisiana & 5 & 5 & 1 & 3 & 2 & 12 & 6 & Very high \\
\hline Cutandia maritima & 2 & 5 & 5 & 5 & 5 & 12 & 6 & Very high \\
\hline Cyperus capitatus & 2 & 5 & 5 & 5 & 5 & 12 & 6 & Very high \\
\hline Elatine alsinastrum & 2 & 5 & 5 & 5 & 5 & 12 & 6 & Very high \\
\hline Erodium rodiei & 5 & 5 & 2 & 2 & 2 & 12 & 6 & Very high \\
\hline Malcolmia ramosissima & 2 & 5 & 5 & 5 & 5 & 12 & 6 & Very high \\
\hline Myosotis pusilla & 2 & 5 & 5 & 5 & 5 & 12 & 6 & Very high \\
\hline Ranunculus millefoliatus & 3 & 5 & 4 & 4 & 4 & 12 & 6 & Very high \\
\hline Riella notarisii & 2 & 5 & 5 & 5 & 5 & 12 & 6 & Very high \\
\hline Rumex hydrolapathum & 2 & 5 & 5 & 5 & 5 & 12 & 6 & Very high \\
\hline Silene petrarchae & 5 & 5 & 2 & 2 & 2 & 12 & 6 & Very high \\
\hline Stachys maritima & 2 & 5 & 5 & 5 & 5 & 12 & 6 & Very high \\
\hline Viola arborescens & 3 & 5 & 3 & 5 & 4 & 12 & 6 & Very high \\
\hline Centaurium favargeri & 3 & 5 & 3.5 & 4 & 3.75 & 11.75 & 7 & High \\
\hline Leucojum aestivum subsp. aestivum & 2 & 5 & 4.5 & 5 & 4.75 & 11.75 & 7 & High \\
\hline Ranunculus garganicus & 5 & 4 & 2.5 & 3 & 2.75 & 11.75 & 7 & High \\
\hline Silene badaroi & 3 & 5 & 3.5 & 4 & 3.75 & 11.75 & 7 & High \\
\hline Teucrium polium subsp. purpurascens & 5 & 4 & 2.5 & 3 & 2.75 & 11.75 & 7 & High \\
\hline Acis nicaeensis & 5 & 3 & 2 & 5 & 3.5 & 11.5 & 8 & High \\
\hline Allium tenuiflorum & 3 & 5 & 2 & 5 & 3.5 & 11.5 & 8 & High \\
\hline Anacamptis longicornu & 3 & 5 & 2 & 5 & 3.5 & 11.5 & 8 & High \\
\hline Aquilegia ophiolitica & 5 & 5 & 2 & 1 & 1.5 & 11.5 & 8 & High \\
\hline Astragalus epiglottis & 3 & 5 & 2 & 5 & 3.5 & 11.5 & 8 & High \\
\hline Cistus crispus & 2 & 5 & 4 & 5 & 4.5 & 11.5 & 8 & High \\
\hline Elatine hydropiper subsp. macropoda & 2 & 5 & 5 & 4 & 4.5 & 11.5 & 8 & High \\
\hline Genista linifolia & 3 & 4 & 4 & 5 & 4.5 & 11.5 & 8 & High \\
\hline
\end{tabular}

Abbreviations: biogeo. $=$ biogeographical, vuln. = vulnerability, artif. $=$ artificialisation.

Table 3

Determination of taxa conservation concerns according to their final scores.

\begin{tabular}{|c|c|c|c|}
\hline Final score & Rank & $\begin{array}{l}\text { Conservation } \\
\text { concern }\end{array}$ & $\begin{array}{l}\text { Number of } \\
\text { taxa }\end{array}$ \\
\hline $12 \leq$ final score $\leq 15$ & $\begin{array}{l}\text { From rank } 1 \text { to } \\
\text { rank } 6\end{array}$ & Priority 1: very high & 37 \\
\hline $9 \leq$ final score $\leq 11.75$ & $\begin{array}{l}\text { From rank } 7 \text { to } \\
\text { rank } 18\end{array}$ & Priority 2: high & 366 \\
\hline $6 \leq$ final score $\leq 8.75$ & $\begin{array}{l}\text { From rank } 19 \\
\text { to rank } 30\end{array}$ & Priority 3: moderate & 374 \\
\hline $3 \leq$ final score $\leq 5.75$ & $\begin{array}{l}\text { From rank } 31 \\
\text { to rank } 42\end{array}$ & Priority 4: low & 136 \\
\hline
\end{tabular}

palustre). Finally, about two thirds of the taxa occur in moderately artificial areas.

\subsection{Comparison of hierarchisation results to red lists and protection lists}

Taxa IUCN status in PACA (Noble et al., 2015) and in Liguria (Arillo et al., 2005) red lists and legal status (European, national or regional protection) were compared to taxa conservation concerns in the present approach (Table 4). These two regional red lists were chosen because they cover administrative areas included for more than a half in the study area. Others red lists cover areas are too different to make a relevant comparison.

PACA red list taxa distribution shows a quite important consistency with conservation concerns defined by the hierarchisation (Table 4). In fact, very high and high concern taxa include $87 \%$ of the critically endangered taxa (CR), $78 \%$ of the endangered taxa (EN), $64 \%$ of the vulnerable taxa (VU) and 53\% of the near-threatened taxa (NT). Only 

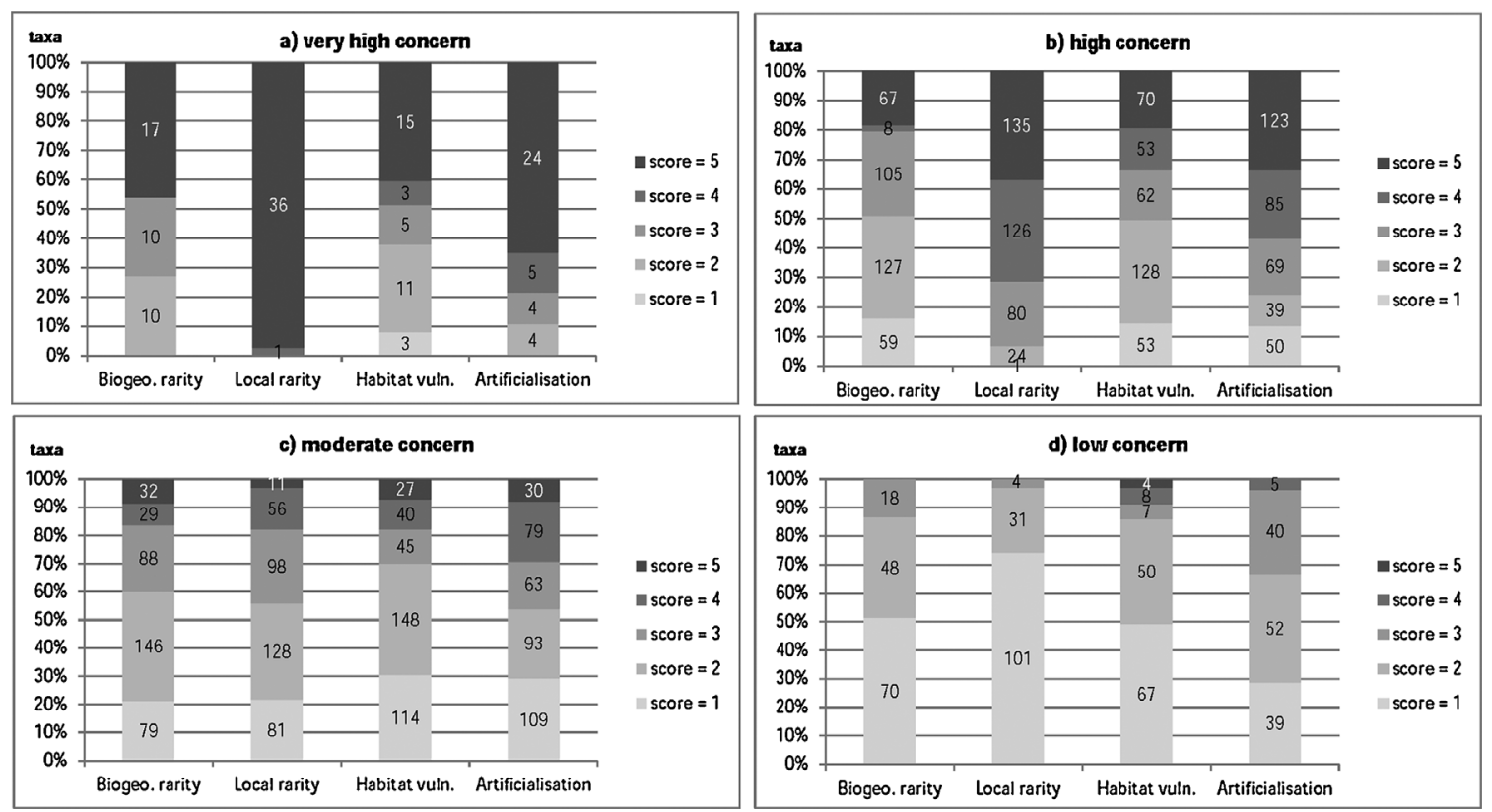

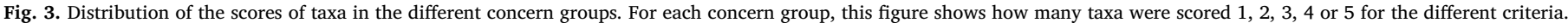
Abbreviations: biogeo. = biogeographical, vuln. = vulnerability.

Table 4

Number of taxa in each concern group according to their IUCN status in PACA and Liguria red lists and according to their protection status in France and in Italy.

\begin{tabular}{|c|c|c|c|c|c|c|}
\hline $\begin{array}{l}\text { Conservation } \\
\text { concern }\end{array}$ & & Very high & High & Moderate & Low & Total \\
\hline \multirow[t]{10}{*}{ PACA red list } & $\mathrm{CR}$ & 9 & 27 & 5 & 0 & 41 \\
\hline & EN & 7 & 64 & 19 & 1 & 91 \\
\hline & VU & 11 & 118 & 70 & 4 & 203 \\
\hline & NT & 3 & 56 & 42 & 10 & 111 \\
\hline & LC & 1 & 50 & 217 & 120 & 388 \\
\hline & $\mathrm{RE}$ & 0 & 1 & 0 & 0 & 1 \\
\hline & NA & 1 & 14 & 1 & 0 & 16 \\
\hline & $\mathrm{DD}$ & 3 & 7 & 7 & 1 & 18 \\
\hline & $\begin{array}{l}\text { Out of PACA } \\
\text { red list }\end{array}$ & 2 & 29 & 13 & 0 & 44 \\
\hline & Total & 37 & 366 & 374 & 136 & 913 \\
\hline \multirow[t]{7}{*}{ Liguria red list } & $\mathrm{CR}$ & 0 & 7 & 8 & 14 & 29 \\
\hline & EN & 0 & 8 & 20 & 5 & 33 \\
\hline & VU & 0 & 2 & 4 & 1 & 7 \\
\hline & LR & 0 & 4 & 9 & 3 & 16 \\
\hline & $\mathrm{DD}$ & 0 & 3 & 1 & 1 & 5 \\
\hline & $\begin{array}{l}\text { Out of Liguria } \\
\text { red list }\end{array}$ & 37 & 342 & 332 & 112 & 823 \\
\hline & Total & 37 & 366 & 374 & 136 & 913 \\
\hline \multirow[t]{5}{*}{ Protection status } & $\begin{array}{l}\text { Fr }+ \text { It } \\
\text { protection }\end{array}$ & 0 & 31 & 58 & 19 & 108 \\
\hline & Fr protection & 25 & 201 & 150 & 31 & 407 \\
\hline & It protection & 0 & 29 & 92 & 84 & 205 \\
\hline & $\begin{array}{l}\text { No protection } \\
\text { status }\end{array}$ & 12 & 105 & 74 & 2 & 193 \\
\hline & Total & 37 & 366 & 374 & 136 & 913 \\
\hline
\end{tabular}

Abbreviations: $\quad \mathrm{CR}=$ Critically $\quad$ endangered,$\quad \mathrm{EN}=$ Endangered,$\quad \mathrm{VU}=$ Vulnerable, NT $=$ Near Threatened, LC $=$ Least Concern, $\mathrm{RE}=$ Regionally Extinct, NA $=$ non-practical, DD = Data Deficient, LR $=$ Low Risk, Fr $=$ France, It $=$ Italy.

one very high concern taxon is a PACA red list least concern taxa (LC): Senecio leucanthemifolius subsp. crassifolius, a strictly coastal taxon. Low and moderate concern taxa include $87 \%$ of the least concern taxa. However, an endangered taxon (Diphasiastrum alpinum) and 4 vulnerable taxa (Allium victorialis, Kalmia procumbens, Lappula deflexa and Lunaria rediviva) were classified as low concern in our hierarchisation. They are widely distributed taxa (boreal or Eurasian) occurring in moderately threatened habitats and moderately artificialised areas. An edge effect is noticed in our results for strictly coastal taxa, which are present only at the border of the study area and so obtained high local rarity and artificialisation scores.

Liguria red list taxa distribution shows a low correlation with concerns defined in our hierarchisation (Table 4 ). In fact, $75 \%$ of critically endangered and endangered taxa, and $70 \%$ of vulnerable taxa are classified moderate or low concern in this hierarchisation. No Liguria red list taxon is classified very high concern.

Taxa distribution according to their conservation concern is not correlated to their legal status. In fact, about $30 \%$ of very high and high concern taxa do not have a protection status, and conversely, all low concern taxa but two (Corallorhiza trifida and Scutellaria alpina) have a protection status in France and/or in Italy. More than $40 \%$ of protected taxa in Italy are classified low concern taxa, and no very high concern taxon is protected in Italy. In this study, about $80 \%$ of taxa benefit from one or several protections statuses. Protected taxa are thus present in all concern groups, as a direct consequence of the initial selection of patrimonial taxa.

\section{Discussion}

\subsection{Methodological choices}

Results from hierarchisation methods can be very different between two different areas, even geographically close, so the area choice is critical. It should be defined in a consistent way either on a biogeographical approach or according to the chosen conservation strategy. The hierarchisation of all patrimonial species in a biogeographical area has the advantage of being consistent with the current challenges for plant conservation, particularly in a biodiversity hotspot where both endemism and threats are high and should be considered together.

Several hierarchisation or classification methods for fauna or flora exist; they can be point-scoring methods or categorical methods. To assess the different criteria, point-scoring methods use either directly the values of criteria (measured or calculated) (e.g. Freitag \& van Jaarsveld, 1997; Redding \& Mooers, 2006; Gaiarsa et al., 2015), or discrete values (scores) with usually the same range for all criteria (e.g. Dunn, Hussell, \& Welsh, 1999; Sapir et al., 2003; Jiménez-Alfaro et al., 2010; Crain \& White, 2011; Bacchetta et al., 2012). The advantage of 
the first approach is a better accuracy of scores, and the advantage of the second one is an easier use for methods including both qualitative and quantitative criteria, and whose values do not follow a normal distribution, as it is the case in this study. To combine the different scores, most of the methods calculate the sum or the average of scores, which lead to the same ranking, weighted or not (e.g. Millsap et al., 1990; Sapir et al., 2003; Reece \& Noss, 2014; Zhang et al., 2015). Other calculations are possible, such as multiplication of scores (e.g. Rodríguez, Rojas-Suárez, \& Sharpe, 2004; Redding \& Mooers, 2006) or factorial summarisation of scores (e.g. Jiménez-Alfaro et al., 2010). Another method to combine criteria is possible, ranking by criteria: all taxa are ranked with a first order criterion, then with a second order criterion, and so on until the last criterion (e.g. Gauthier et al., 2010; Bacchetta et al., 2012). Combining scores in an only priority index is subject to methodological uncertainties because many different mathematical processes are possible. Selected criteria, their weighting, different ways to assess and combine scores can give very different outcomes (Carter et al., 2000; Jiménez-Alfaro et al., 2010; Reece \& Noss, 2014), so we must be attentive in the method choice according to the study goal.

Four different applications of the Gauthier et al. (2010) method were already published (Gauthier et al., 2013; Kricsfalusy \& Trevisan, 2014; Maciel et al., 2016; Schatz et al., 2014), and all of them adapted criteria assessment to their specific context. Our approach was also adapted to match our specific aims and constraints, which are distinctive features of regional biodiversity hotspots. Regional responsibility is here called biogeographical rarity and takes into account endemism (Gauthier et al., 2013), and distribution disjunctions and limits. Taking into account peripheral populations should not be neglected because they can potentially present local adaptations enabling them to better face global changes (Bonin et al., 2007; Crain \& White, 2011; Papuga, 2016). Knowledge improvement through geo-localised observation data and connecting databases enables a more accurate assessment of the local rarity criterion. Using a randomly placed uniform grid reduces bias. The habitat vulnerability criterion of Gauthier et al. (2010) was turned into a threat criterion, adding an artificialisation criterion, which has a significant impact on the study area (Lhotte, Affre, \& Saatkamp, 2014; Vimal et al., 2012), and whose exponential increase these last decades is a major concern in urban planning policies in the European Union (Meiner, Georgi, Petersen, \& Uhel, 2010; Virely, 2017). In fact, land consumption due to urban development is a major concern because they mostly are non-renewable resources: land use changes to build houses or roads are usually permanent, or reversible only at very high costs (Ludlow, 2006). Other studies based on this method chose to use two or three sub-criteria to assess habitat vulnerability (Gauthier et al., 2013; Kricsfalusy \& Trevisan, 2014). Assessment of habitat vulnerability remains delicate and needs an expert assessment which can be subjective, but bias can be reduced using the Delphi technique (Hsu \& Sandford, 2007; Mukherjee et al., 2015). Finally, we used the sum of scores summarisation method to give the same weight to the different rarity and threat criteria, enabling to highlight in very high and high concerns locally rare taxa, or biogeographically rare taxa, or threatened taxa.

\subsection{Hierarchisation contribution for taxa conservation}

This hierarchisation draws up a typology of high conservation concern taxa, to better understand risks for taxa according to their rarity kind and threats, in order to implement adapted conservation actions (Pärtel et al., 2005). In fact, criteria scores reflect rarity or vulnerability of taxa, giving us a first idea about what to do to preserve them. The great majority of very high and high concern taxa are locally rare $(94 \%$ of these taxa obtained a score of 4 or 5 for local rarity criterion), so this criterion is determining. Nevertheless, other criteria enable to distinguish two kinds of rarity: some taxa are naturally scarce, usually adapted to live in reduced and isolated populations (e.g. Acis nicaeensis), whereas others became rarer following disturbing events due to human impacts (e.g. Limonium sp.) (Gaston, 1994). Besides being locally rare, taxa of very high concern are generally threatened by surface artificialisation. The study area suffered these last decades from deep socio-economic changes which substantially modified ecosystemic dynamic tendencies (i.e. Barbero, Bonin, Loisel, \& Quézel, 1990). These serious environment changes led to the rarefaction or even extinction of several populations. Scores obtained for each criterion will enable us to target conservation or monitoring actions adapted for each taxon, taking into account the need for conservation actions, the expected benefit, the success probability and the cost of conservation actions (Joseph et al., 2009).

\subsection{An approach complementing red lists and protection lists}

Differences between red lists status and our hierarchisation results are mainly due to differences between chosen criteria and between application areas. Red lists of threatened species are developed to assess extinction risks of taxa in a given area, and are based on five criteria: (A) population size reduction, (B) extent of occurrence or area of occupancy, (C) small population size and decline, (D) very small or restricted population, and (E) quantitative analysis (IUCN, 2012). However, neither of these criteria report biogeographical rarity (except in the case of a global IUCN assessment) nor habitat vulnerability. Although threats and local rarity criteria seem quite close to IUCN criteria, hierarchisation results are noticeably different from red lists outcomes. This difference is more significant for the Liguria red list. In fact, if 869 taxa (95\%) assessed in our hierarchisation are also assessed in the PACA red list, only 90 taxa (9\%) assessed in our hierarchisation are also assessed in the Liguria red list, due to the geographical distribution of the study area, shared unevenly between France and Italy. Consequently, many common taxa in the South-Western Alps reach their distribution limit in Liguria, where they tend to be rather rare and threatened. Red lists have the advantage of taking into account the edge effect and to anticipate taxonomic sensitivity using a data deficient (DD) category, for little known taxa or controversial taxonomic value taxa. A hierarchisation carried out in a biogeographical territory, even as heterogeneous as the South-Western Alps, enables to provide components required to implement a long term biogeographical conservation, whereas red lists face urgency. Finally, red lists cannot be used directly, but they embody a critical first step before conservation actions priority-setting (Fitzpatrick et al., 2007; Rodríguez et al., 2004).

These hierarchisation results are not correlated to national or regional protection lists of species in France and in Italy. Gauthier et al. (2010) also noticed a low consistency between the results of their hierarchisation and regional protection lists in Languedoc-Roussillon. In this study, the major part of assessed taxa is already protected, so this hierarchisation is especially important to define priorities between those taxa. Conversely, more than half of non-protected taxa are classified as very high or high concern: highlighting these taxa will enable to implement efficient conservation measures. The divergence between protection lists and taxa concern in our study can be explained for different reasons. Firstly, protection lists were set up more than 20 years ago, and knowledge improved greatly since then, especially in terms of computing technology, which highlighted the rarity status of all species. Secondly, protection lists were set up using expert opinion, whereas our approach was based a standard method. Thirdly, some species were obviously put on protection lists to protect their habitat, even if they were not especially rare. Fourthly, protection lists usually don't include species growing in agricultural systems. Fifthly, protection lists considered administrative areas and not a biogeographical area as we did. Therefore, a lot high or very high concern are not protected.

If administrative approaches enable to ensure populations' protection in a given area, they do not incorporate the global distribution of taxa. The weakness of administrative approaches is mostly felt around 
the borders, and when study areas are not equally divided between countries (here for example, $88 \%$ of the study area is located in France). Thus, red lists and protection lists do not provide information about taxa conservation priorities, because they were not developed for this purpose. Therefore, hierarchisation of taxa is a complementary approach which enables to orientate conservation strategies in a transparent way.

\section{Conclusion}

To focus on a regional biodiversity hotspot matching the distribution of numerous endemic species, and submitted to high artificialisation levels, the hierarchisation method must be improved in order to take into account the two most important parameters. In this context, we classified taxa into concern priorities to best allocate available resources for conservation actions for patrimonial taxa. This hierarchisation is versionable and progressive with knowledge improvement and land cover changes, and will be regularly updated. The discrepancy between our approach and red lists and protection lists highlights a strong requirement to implement a strategy taking into account the cross-border context, with shared information and data standards. In this context, our results show an important need for a collaborative work between countries and regions for an efficient conservation of patrimonial flora, especially those not listed in the red lists and protection lists. It is important to keep in mind that no hierarchisation system can give the « right answer » for all taxa or all users, whatever the number of included criteria or the way to combine them. Differences between categorisation systems are less important than the need to implement these processes, as long as objectives are well defined, to develop strategies to make conservation actions more efficient (Dunn et al., 1999). In this way, we used a standard and robust method, already used in different contexts around the world, and strengthened it in considering the parameters enabling to define a biodiversity hotspot: endemic species richness and habitat loss risk.

\section{Acknowledgements}

This work was supported by FEDER funds from European program Alcotra n ${ }^{\circ} 258$ Natura 2000 ADM Progres, the Provence-Alpes-Côted'Azur (PACA) region, and the Direction Régionale de l'Environnement, de l'Aménagement et du Logement Provence-Alpes-Côte d'Azur (DREAL PACA). The authors thank Benoît Offerhaus, Chiara Montagnani, Francesca Magillo and Fulvio Dente for habitat assessment; Olivier Gavotto, Guilhem Debarros, Henri Michaud, Jérémie Van Es and JeanCharles Villaret for data processing and validation; Guillaume Papuga for reviewing the manuscript; and Benoît Strauss for English language improvement.

\section{References}

Aeschimann, D., Lauber, K., Moser, D. M., \& Theurillat, J.-P. (2004). Flora Alpina. Paris: Belin.

Aeschimann, D., Rasolofo, N., \& Theurillat, J.-P. (2011). Analyse de la flore des Alpes. 1: historique et biodiversité. Candollea, 66, 27-55.

Arillo, A., Barberis, G., Birindelli, S., Calvini, M., Cassulo, L., Ciuffardi, L., et al. (2005). Lista rossa regionale delle specie presenti in Liguria incluse nell'allegato II della direttiva CEE 43/92 e nell'allegato I della direttiva CEE 409/79. Rapporti tecnici Libioss. Genova: Regione Liguria, Osservatorio regionale per la biodiversita.

Bacchetta, G., Farris, E., \& Pontecorvo, C. (2012). A new method to set conservation priorities in biodiversity hotspots. Plant Biosystems, 146, 638-648.

Bajjouk, T., Guillaumont, B., Michez, N., Thouin, B., Croguenne, C. C., Populus, J., et al. (2015a). Classification EUNIS, Système d'information européen sur la nature : Traduction française des habitats benthiques des Régions Atlantique et Méditerranée. Habitats Littoraux, Vol. 1. France: IFREMER, JNCC, MNHN.

Bajjouk, T., Guillaumont, B., Michez, N., Thouin, B., Croguennec, C., Populus, J., et al. (2015b). Classification EUNIS, Système d'information européen sur la nature: Traduction française des habitats benthiques des Régions Atlantique et Méditerranée. Habitats subtidaux \& complexes d'habitats, Vol. 2. France: IFREMER, JNCC, MNHN.

Barbero, M., Bonin, G., Loisel, R., \& Quézel, P. (1990). Changes and disturbances of forest ecosystems caused by human activities in the western part of the Mediterranean basin. Vegetatio, 87, 151-173.

Bensettiti, F., Puissauve, R., Lepareur, F., Touroult, J., \& Maciejewski, L. (2012). Evaluation de l'état de conservation des habitats et des espèces d'intérêt communautaire Guide méthodologique. Rapport SPN 2012-27. Paris: SPN, MNHN.

Berg, C., Abdank, A., Isermann, M., Jansen, F., Timmermann, T., \& Dengler, J. (2014) Red lists and conservation prioritization of plant communities - a methodological framework. Applied Vegetation Science, 17, 504-515.

Bonin, A., Nicole, F., Pompanon, F., Miaud, C., \& Taberlet, P. (2007). Population adaptive index: A new method to help measure intraspecific genetic diversity and prioritize populations for conservation. Conservation Biology, 21, 697-708.

Cardinale, B. J., Duffy, J. E., Gonzalez, A., Hooper, D. U., Perrings, C., Venail, P., et al. (2012). Biodiversity loss and its impact on humanity. Nature, 486, 59-67.

Carter, M. F., Hunter, W. C., Pashley, D. N., \& Rosenberg, K. V. (2000). Setting conservation priorities for landbirds in the United States: the partners in flight approach. The Auk, 117, 541-548.

Casazza, G., Zappa, E., Mariotti, M. G., Médail, F., \& Minuto, L. (2008). Ecological and historical factors affecting distribution pattern and richness of endemic plant species: The case of the Maritim and Ligurian Alps hotspot. Diversity and Distributions, 14, 47-58.

Coates, D. J., \& Atkins, K. A. (2001). Priority setting and the conservation of Western Australia's diverse and highly endemic flora. Biological Conservation, 97, 251-263.

Crain, B. J., \& White, J. W. (2011). Categorizing locally rare plant taxa for conservation status. Biodiversity and Conservation, 20, 451-463.

De Lange, H. J., Sala, S., Vighi, M., \& Faber, J. H. (2010). Ecological vulnerability in risk assessment - A review and perspectives. Science of the Total Environment, 408, 3871-3879.

Dunn, E. H., Hussell, D. J. T., \& Welsh, D. A. (1999). Priority-setting tool applied to Canada's landbirds based on concern and responsibility for species. Conservation Biology, 13, 1404-1415.

Fitzpatrick, U., Murray, E. T. E., Paxton, R. J., \& Brown, M. J. F. (2007). Building on IUCN regional red lists to produce lists of species of conservation priority: A model with Irish bees. Conservation Biology, 21, 1324-1332.

Freitag, S., \& van Jaarsveld, A. S. (1997). Relative occupancy, endemism, taxonomic distinctiveness and vulnerability: Prioritizing regional conservation actions. Biodiversity and Conservation, 6, 211-232.

Gaiarsa, M. P., Alencar, L. R. V., Valdujo, P. H., Tambosi, L. R., \& Martins, M. (2015). Setting conservation priorities within monophyletic groups: An integrative approach. Journal for Nature Conservation, 24, 49-55.

Gargominy, O., Tercerie, S., Daszkiewicz, P., Régnie, C., Ramage, T., Dupont, P., et al. (2012). TAXREF v5.0, référentiel taxonomique pour la France : mise en oeuvre et diffusion. Paris: SPN.

Gaston, K. J. (1994). Rarity. London: Chapman \& Hall.

Gauthier, P., Debussche, M., \& Thompson, J. D. (2010). Regional priority setting for rare species based on a method combining three criteria. Biological Conservation, 143, 1501-1509.

Gauthier, P., Foulon, Y., Jupille, O., \& Thompson, J. D. (2013). Quantifying habitat vulnerability to assess species priorities for conservation management. Biological Conservation, 158, 321-325.

Henle, K., Bauch, B., Auliya, M., Kulvik, M., Pe'er, G., Schmeller, D. S., et al. (2013). Priorities for biodiversity monitoring in Europe: A review of supranational policies and a novel scheme for integrative prioritization. Ecological Indicators, 33, 5-18.

Hsu, C.-C., \& Sandford, B. A. (2007). The Delphi technique: making Sens of consensus. Practical Assessment, Research and Evaluation, 12, 1-8.

IUCN (2012). (International Union for Conservation of Nature)IUCN red list categories and criteria: version 3.1 (second edition). Gland and Cambridge: IUCN.

Jiménez-Alfaro, J., Colubi, A., \& González-Rodríguez, G. (2010). A comparison of pointscoring procedures for species prioritization and allocation of seed collection resources in a mountain region. Biodiversity and Conservation, 19, 3667-3684.

Joseph, L. N., Maloney, R. F., \& Possingham, H. P. (2009). Optimal allocation of resources among threatened species: A project prioritization protocol. Conservation Biology, 23, 328-338.

Keller, V., \& Bollmann, K. (2004). From red lists to species of conservation concern. Conservation Biology, 18, 1636-1644.

Kricsfalusy, V. V., \& Trevisan, N. (2014). Prioritizing regionally rare plant species for conservation using herbarium data. Biodiversity and Conservation, 23, 39-61.

Ladle, R., \& Whittaker, R. J. (2011). Conservation biogeography. West Sussex: John Wiley \& Sons Ltd.

Lhotte, A., Affre, L., \& Saatkamp, A. (2014). Are there contrasted impacts of urbanization and land uses on population persistence? The case of Teucrium pseudochamaepitys, an endangered species in Southern France. Flora, 209, 484-490.

Louvel, J., Gaudillat, V., \& Poncet, L. (2013). EUNIS, European nature information system, Système d'Information européen sur la Nature. Classification des habitats. Traduction française. Habitats terrestres et d'eau douce. Paris: MNHN-DIREV-SPN, MEDDE.

Ludlow, D. (2006). Urban sprawl in europe: the ignored challenge. Luxembourg: European Environment Agency.

Mace, G. M., Possingham, H. P., \& Leader-Williams, N. (2007). Prioritizing choices in conservation. In D. Macdonald, \& K. Service (Eds.). Key topics in conservation biology (pp. 17-34). Oxford: Blackwell Publishers.

Maciel, E. A., Oliveira-Filho, A. T., \& Eisenlohr, P. V. (2016). Prioritizing rare tree species of the Cerrado-Amazon ecotone: warnings and insights emerging from a comprehensive transitional zone of south America. Nature \& Conservation, 14, 74-82.

Marsh, H., Dennis, A., Hines, H., Kutt, A., McDonald, K., Weber, E., et al. (2007). Optimizing allocation of management resources for wildlife. Conservation Biology, 21, 387-399.

Martín, J. L., Cardoso, P., Arechavaleta, M., Borges, P. A. V., Faria, B. F., Abreu, C., Aguiar, A. F., Carvalho, J. A., Costa, A. C., Cunha, R. T., Fernandes, F. M., Gabriel, R., 
Jardim, R., Lobo, C., Martins, A. M. F., Oliveira, P., Rodrigues, P., Silva, L., Teixeira, D., Amorim, I. R., Homem, N., Martins, B., Martins, M., \& Mendonça, E. (2010). Using taxonomically unbiased criteria to prioritize resource allocation for oceanic island species conservation. Biodiversity and Conservation, 19, 1659-1682.

Médail, F., \& Diadema, K. (2006). Biodiversité végétale méditerranéenne et anthropisation: Approches macro et micro-régionales. Ann. de géogr. 651, 618-640.

Médail, F., \& Diadema, K. (2009). Glacial refugia influence plant diversity patterns in the Mediterranean basin. Journal of Biogeography. 36, 1333-1345.

Médail, F. \& Myers, N. (2004). Mediterranean basin. In R. A. Mittermeier, P. Robles Gil, M. Hoffmann, J. Pilgrim, T. Brooks, C. G. Mittermeier, J. Lamoreux, \& G. A. B. da Fonseca (Eds.). Hotspots revisited: Earth's biologically richest and most endangered terrestrial ecoregions (pp. 144-147). Washington: Conservation International, \& Mexico: Agrupación Sierra Madre Monterrey: CEMEX.

Médail, F., \& Verlaque, R. (1997). Ecological characteristics and rarity of endemic plants from southeast France and Corsica: Implications for biodiversity conservation. Biological Conservation, 80, 269-281.

Meiner, A., Georgi, B., Petersen, J., \& Uhel, R. (2010). The european environment, state and outlook 2010: land use. Copenhagen: European Environment Agency.

Millennium Ecosystem Assessment (2005). Ecosystems and human well-being: biodiversity synthesis. Washington DC: World Resources Institute.

Miller, R. M., Rodriguez, J. P., Aniskowicz-Fowler, T., Bambaradeniya, C., Boles, R., Eaton, M. A., et al. (2006). Extinction risk and conservation priorities. Science, 313, 441.

Millsap, B. A., Gore, J. A., Runde, D. E., \& Cerulean, S. I. (1990). Setting priorities for the conservation of fish and wildlife species in Florida. Wildlife Monographs, 111, 1-57.

Mukherjee, N., Huge, J., Sutherland, W. J., McNeill, J., Opstal, M. V., Dahdouh-Guebas, F., et al. (2015). The Delphi technique in ecology and biological conservation: Applications and guidelines. Methods in Ecology and Evolution, 6, 1097-1109.

Myers, N., Mittermeier, R. A., Mittermeier, C. G., da Fonseca, G. A. B., \& Kents, J. (2000). Biodiversity hotspots for conservation priorities. Nature, 403, 853-858.

Noble, V., \& Diadema, K. (sous la direction de) (2011). La flore des Alpes-Maritimes et de la Principauté de Monaco. Originalité et diversité. Turriers: Naturalia Publications.

Noble, V., Van Es, J., Michaud, H., \& Garraud, L. (coord.). (2015). Liste Rouge de la flore vasculaire de Provence-Alpes-Côte d. France: DREAL PACA, Région PACA.

Papuga, G. (2016). Comparative studies of ecological niche variation among central and peripheral populations of mediterranean endemic plants. Ph.D. thesis. Italy: University of Sassari.

Pärtel, M., Kaameles, R., Reier, U., Tuvi, E.-L., Roosaluste, E., Vellak, A., et al. (2005). Grouping and prioritization of vascular plant species for conservation: Combining natural rarity and management need. Biological Conservation, 123, 271-278.

Pignatti, S. (1982). Flora d'Italia. Edagricole: Milano.

Pullin, A. S., Sutherland, W., Gardner, T., Kapos, V., \& Fa, J. E. (2013). Conservation priorities: Identifying need, taking action and evaluating success. In D. W. Macdonald, \& K. J. Willis (Eds.). Key topics in conservation biology 2 (pp. 3-22) Oxford: John Wiley \& Sons.

Redding, D. W., \& Mooers, A. O. (2006). Incorporating evolutionary measures into conservation prioritization. Conservation Biology, 20, 1670-1678.
Reece, J. S., \& Noss, R. F. (2014). Prioritizing species by conservation value and vulnerability: A new index applied to species threatened by sea-level rise and other risks in Florida. Natural Areas Journal, 34, 31-45.

Rodrigues, A. S. L., Akçakaya, H. R., Andelman, S. J., Bakarr, M. I., Boitani, L., Brooks, T. M., et al. (2004). Global Gap analysis: Priority regions for expanding the global protected-area network. BioScience, 54, 1092-1100.

Rodríguez, J. P., Rojas-Suárez, F., \& Sharpe, C. J. (2004). Setting priorities for the conservation of Venezuela's threatened birds. Oryx, 38, 373-382.

Rossi, G., Montagnani, C., Gargano, D., Peruzzi, L., Abeli, T., Ravera, S., et al. (2013). Lista Rossa della Flora Italiana. 1. Policy Species e altre specie minacciate. Italia: Comitato Italiano IUCN e Ministero dell'Ambiente e della Tutela del Territorio e del Mare.

Salanon, R., Grandili, J.-F., Kulesza, V., \& Pintaud, J.-C. (1994). La flore littorale des Alpes-Maritimes : Evolutions depuis le XIXe siècle et bilan actuel. Biocosme Mésogéen, 11, 53-329.

Sapir, Y., Shmida, A., \& Fragman, O. (2003). Constructing red numbers for setting conservation priorities of endangered plant species: Israeli flora as a test case. Journal for Nature Conservation, 11, 91-107.

Schatz, B., Gauthier, P., Debussche, M., \& Thompson, J. D. (2014). A decision tool for listing species for protection on different geographic scales and administrative levels. Journal for Nature Conservation, 22, 75-83.

Schmeller, D. S., Gruber, B., Bauch, B., Lanno, K., Budrys, E., Babij, V., et al. (2008). Determination of national conservation responsibilities for species conservation in regions with multiple political jurisdictions. Biodiversity and Conservation, 17, 3607-3622.

Takhtajan, A. (1986). Floristic regions of the world. Berkeley, Los Angeles, London: University of Califonia Press.

Tison, J.-M., Jauzein, P., \& Michaud, H. (2014). Turriers: Naturalia Publications. Flore de la France méditerranéenne continentale.

Tison, J.-M., \& de Foucault, B. (coord.). (2014). Flora Gallica. Flore de France. Mèze: Biotope.

UICN France, FCBN, MNHN (2012). La Liste rouge des espèces menacées en France-Chapitre Flore vasculaire de France métropolitaine : premiers résultats pour 1000 espèces. sousespèces et variétés. France: UICN France, FCBN, MNHN.

Vimal, R., Geniaux, G., Pluvinet, P., Napoleone, C., \& Lepart, J. (2012). Detecting threatened biodiversity by urbanization at regional and local scales using an urban sprawl simulation approach: Application on the French Mediterranean region. Landscape and Urban Planning, 104, 343-355.

Virely, B. (2017). Artificialisation : de la mesure à l'action. Paris: SEEIDD, CGDD.

Vitousek, P. M. (1994). Beyond global warming: Ecology and global change. Ecology, 75, 1861-1876.

Wilson, K. A., Carwardine, J., \& Possingham, H. P. (2009). Setting conservation priorities. The Year in Ecology and Conservation Biology - Annals of the New York Academy of Sciences, 1162, 237-264.

Zhang, X., Gao, X., Wang, J., \& Cao, W. (2015). Extinction risk and conservation priority analyses for 64 endemic fishes in the upper Yangtze River, China. Environmental Biology of Fishes, 98, 261-272. 